\title{
Factors Influencing the Engagement of Rural Youths in Off-Farm Income Generating Activities in Developing Countries: Evidence from Ethiopia, Wolaita Zone
}

\author{
Samuel Semma Waje \\ Department of Food Security, Wolaita Sodo, Ethiopia \\ Email address: \\ Samuelsemma4@gmail.com
}

To cite this article:

Samuel Semma Waje. Factors Influencing the Engagement of Rural Youths in Off-Farm Income Generating Activities in Developing Countries: Evidence from Ethiopia, Wolaita Zone. International Journal of Economics, Finance and Management Sciences.

Vol. 7, No. 4, 2019, pp. 131-141. doi: 10.11648/j.ijefm.20190704.15

Received: August 18, 2019; Accepted: August 30, 2019; Published: September 19, 2019

\begin{abstract}
Ethiopia is one of the poorest countries in the world with high rate of unemployment of youths. This rate is higher in rural than urban areas. Income generating activities play a vital role to improve the livelihood of rural people in developing countries. Many rural youths are faced with difficulty of maintaining livelihoods and consequently, poverty remains pervasive among them. The paper examined the engagement of rural youths in off-farm or non-agricultural income generating activities as well as factors influencing their involvement in Soddo and Areka towns in wolaita zone, Ethiopia. The purposes of this research are to explicitly enquiry and consider aspects that are influencing the engagement of rural youths in off-farm income generating activities in Sodo and Areka towns in wolaita zone. The study was utilized causal research design to achieve the research objectives. The target population under study is all youth groups in the ten off-farm income generating activities in both Sodo and Areka towns. The study was conducted from July 2018 to August 2019. In this study, primary and secondary data types and sources were used. The instruments to collect primary data were questionnaires. Sample size was 306 which determined by using Yamane (1967) formula and individual informants were selected via stratified random sampling technique. The data collected was analyzed quantitatively and qualitatively by the aid of SPSS. V.16. The finding of the study showed that the variables (entrepreneurial, technology, institutional, cultural, financial, socio-economical, psychological and infrastructural factors affecting the engagement of rural youths off-farm income generating activities both in Sodo and Areka towns in Wolaita zone, Ethiopia which were explained the variance of $73.7 \%$ and $26.3 \%$ of the variance was explained by other factors which are not the part of this study variables. Hence, stakeholders who focus on the engagement, promotion, encouragement and expansion of off-farm income diversification are expected to enhance entrepreneurial and psychological motivation to the youths.
\end{abstract}

Keywords: Engagement, Income Generating, Off-farm, Youth

\section{Introduction}

Income generation simply means gaining or increasing income or money that an individual or business receives in exchange for providing a good or service after investing capital. It can also be defined as small scale projects that create an income source to individual beneficiaries or beneficiary group whilst promoting; the principal right of self-determination and the objectives of integration, reputation and re-integration [8]. In (2010) Food and Agricultural Organization (FAO) asserted that with the increasing male migration, women are becoming the sole producers of the food for the maintenance of the family, this shows that women play a major role in traditional activities such as subsistence food production, household chores, food processing, home crafts market trade etc.

Engagement is a process of working collaboratively with and for groups of people allied by geographical proximity, special interest, or similar situations to address issues affecting their well-being [11]. Engagement is an action dependent on the openness of structures that allows individuals to participate and operate within the network of 
ties and groups through which they get drawn into communities [8].

The organized groups create and increase economic activities as well as financial services by providing loans. The result is accessibility to poor households to either alleviate poverty or slow it down [3]. The groups are known for providing useful sums of money to the poor households to start income generating activities and or improve their businesses [3]. According to the World Bank (2001), poverty has various manifestations which can be linked to the lack of income and assets to attain basic necessities of life, such as, food, shelter, clothing and acceptable levels of health and education.

For Pettigrew (1979), organizational culture consists of "a system of public and collective meanings accepted by a given group over a certain period of time. This system of terms, forms, categories and images interpret for people their own situations". However, for Schein (1992), organizational culture is to be understood as "the pattern of shared basic assumptions that a given group has invented, discovered, or developed in learning to cope with its problems of external adaptation and internal integration -- a pattern of assumptions that has worked well enough to be considered valid and, therefore, to be taught to new members as the correct way to perceive, think and feel in relation to those problems". Public corporations emphasis is on valuing a centralized and authoritarian system of authority that makes it difficult to increase professional development and to acknowledge the human element (rigid hierarchical power structure). In as much as the public companies emphasize individual competence and efficiency as a way to achieve the highly desired personal objectives, they implicitly stimulate the necessity of "passing over" colleagues who have longed for similar objectives (competitive professionalism). Such values manifest themselves through practices that aim at the implementation of interpersonal communication strategies and decision-making tactics that enhance the aforementioned power structure. In other words, the culture of the public companies that have taken part in this research can be fundamentally defined by valuing authority and competition, detrimental to the human element and to interpersonal relations, as a means of climbing the hierarchy [4].

\subsection{Statement of the Problem}

There is an increasing concern across the globe by Governmental, non-governmental organizations, and World Bank on various policies, over the engagement of rural youth in income generating activities (IGAs), so as to address rural poverty, both in terms of reduction strategies as well as generally, to promote rural advancement. In Africa and indeed in Ethiopia, it was evident that, poverty is rampant in rural areas, than in urban areas, and youths are the main victims [19]. The majority of the poor lives in rural areas, with severity of destitution, far greater than in urban areas. These trends are expected to persist in the predictable future. $70 \%$ of the world's poor people live in rural areas in developing countries [6]. Their livelihoods usually depend either directly or indirectly on agriculture and non agriculture activities. Engagement of rural youths in developmental activities is facing a serious challenge in several developing countries, for example in Tanzania [7,9].

Rural areas in Ethiopia most youths are the most neglected, in terms of government's developmental policies despite the fact that, rural areas serve as the most populated [4] they remain unattractive for living as a result of the absence of infrastructural development such as portable drinking water, road networks and electricity that will improve the quality of people's lives. It is imperative to consider income, as an important dimension of livelihood, thus the upliftment of the living standard of the poor rural youth women and men could only be achieved when they earn from their income generating activities. There is need for the engagement of rural youths to contribute to the development process, though they are constrained by different factors such as work culture of the area, psychological (self-determination) financial, socio-economic problems [3].

In Ethiopia the birth rate is increasing alarmingly and $70 \%$ of the total population occupies youths [5]. Unemployment problem is one of the critical problems in the country. Peoples living in rural towns were migrating to the towns to get job opportunities; still there exists big gap between job opportunities and the demand of youths. Most of the youths are not engaged in income generating activities/IGAs/. There also exist a number of opportunities for rural youths to engage in income generating activities. One of the vast opportunities is off-farm income generating activities. In 2014 the Ethiopian government, presented a policy program aiming to reduce unemployment and to alleviate poverty as Rural and Towns job creation package at a country level, which is extended to regions zones woredas (districts) and kebele levels. The vision of this package is to empower mainly, economically. One of the strategies includes the engagement youths in income generating activities [18]. In terms of economic growth, the package serves as an avenue and plays a vital role in engagement in income generation and participation in economic activities, such as non-farm activities (e.g. small constructions, small manufacturing, petty trades, carpentry, men and women beauty salons, small transportations, local coffee preparations and selling, shoe shining and repairing, etc), generating employment opportunities and other economic activities which will allow development in the area.

This study therefore seeks to examine the significant factors influencing the engagement of rural youths in off farm income generating activities/IGAs/ in Sodo and Areka towns wolaita zone, Ethiopia.

\subsection{Hypotheses of the Study}

In line with the broad purpose statement the following hypotheses were also formulated for investigation. Hypotheses of the study stands on the theories related to offfarm IGAs that has been developed over the years by income generating activities areas researcher's and past empirical 
studies related to a IGAs. Hence, based on the objective, the present study seeks to test the following 8 hypotheses:

$\mathrm{H}_{\mathrm{O}} 1$ : There is significant influence of entrepreneurial factors on the engagement of rural youths in off-farm IGAs.

$\mathrm{H}_{\mathrm{O}}$ 2: There is significant influence of technological factor on the engagement of rural youths in off-farm IGAs.

$\mathrm{H}_{\mathrm{O}} 3$ : There is significant influence of institutional factor on the engagement of rural youths in off-farm IGAs.

$\mathrm{H}_{\mathrm{O}} 4$ : There is significant influence of cultural factors on the engagement of rural youths in off-farm IGAs.

$\mathrm{H}_{\mathrm{O}}$ 5: There is significant influence of financial factors on the engagement of rural youths in off-farm IGAs

$\mathrm{H}_{\mathrm{O}}$ 6: There is significant influence of socio- economic factors on the engagement of rural youths in off-farm IGAs.

$\mathrm{H}_{\mathrm{O}}$ 7: There is significant influence of psychological factors on the engagement of rural youths in off-farm IGAs.

$\mathrm{H}_{\mathrm{O}} 8$ : There is significant influence of infrastructural factors on the engagement of rural youths in off-farm IGAs.

\subsection{Objectives of the Study}

\subsubsection{General Objectives}

The main objective of this study is to investigate factors influencing the engagement of youths in off-farm income generating activities/IGAs/ in Soddo and Areka Towns in wolaita Zone, Ethiopia.

\subsubsection{Specific Objectives}

1. To assess the internal obstacles those affecting the engagement of youths in off-farm IGAs in the Sodo and Areka towns in Wolaita Zone.

2. To examine the major external impediments to rural youths of engagement in off-farm IGAs in Sodo and Areka towns in Wolaita Zone.

Conceptual Framework

Building a conceptual model is done on the basis of theoretical knowledge of the engagement in income generating activities affecting factors, the nature, its properties and the interrelationships should be identified and structured in to a framework. This conceptual model gives an exact idea of the research problem and shows its various properties and variables to be studied. To organize in a line the conceptual framework with the research objectives, the engagement of youths in off-farm Income generating Activities/IGAs/ is the dependent variable and hampering factors will be independent variables. The relationship can be expressed and shown in the Figure 1 below.

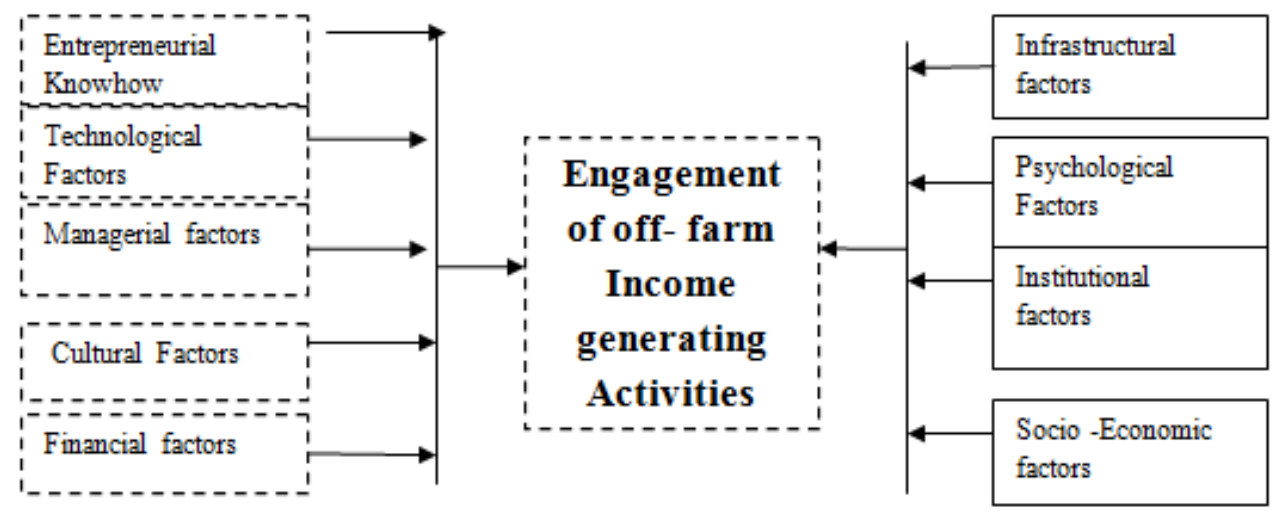

Figure 1. Conceptual Framework (Researcher 2019).

\section{Data and Research Methodology}

\subsection{Research Design}

The research design that would be employed under this study was causal. The major purpose of the casual research design is it concerned with specifying and interpreting relationships between predictor variables, the relationship between outcome variables would be correlated with an aim of estimating the integrated influence of the factors on the engagement of off-farm income generating activities of youths in both Sodo and Areka towns. Moreover the data were described, correlated and finally predictions were made to the combined effect of internal and external obstacles that hinder the engagement of youths in off-farm IGAs.

\subsection{Sampling Procedures}

Sodo and Areka towns were purposely chosen as a study area for this research. This is because most of off-farm IGAs engaged youths were found in these towns. Second, the two towns were selected based on their nearness and convenience to collect data in short time.

\subsubsection{The Population of Study}

The target population consists of the youth groups registered in the past five Ethiopian fiscal years operating their business in all of the ten off-farm IGAs in Sodo and Areka towns in Wolaita zone, Ethiopia. The registered youth groups' data could be obtained from the records of Wolaita zones' job opportunity creation departments.

\subsubsection{Sampling Technique}

This study was employed a stratified random sampling technique; sampling frames were youth groups those are engaged in off farm income generating activities. This technique was preferred because sampling frame would be organized into relatively homogeneous groups or strata before selecting elements for the sample. In each strata element there are heterogeneous groups. This step increases 
the probability that the final sample would be representative in terms of the stratified groups.

\subsubsection{Sample Size}

This study applied a simplified sample size determination formula provided in order to determine the required sample size at $95 \%$ confidence with the level of precision 5\% [20]. This sample size determination method is more applicable when the sampling population is known and finite and it is also statistically permutable to commit 0.01 to 0.1 level of bias in study process and to determine the required sample size the following Yamane formula applied in this study below:-

$$
\begin{aligned}
& \frac{N}{1+N(e 2)} \\
& \frac{2036}{1+2036(0.05) 2)}=\frac{2036}{7.65}=306
\end{aligned}
$$

Therefore, the sample size of this study will be $n=306$, Where

i. $\mathrm{n}$ - is the sample size, $=306$

ii. $\mathrm{N}$ - is the population size, $=2036$

iii. $\mathrm{e}$ - is the level of precision (sampling error) $=5 \%$

\begin{tabular}{|c|c|c|c|c|c|c|c|}
\hline \multirow{2}{*}{ s/no } & \multicolumn{4}{|l|}{ Youth groups engaged in Off-farm Income generating activities } & \multicolumn{3}{|c|}{ Sample size } \\
\hline & Sub sectors & Sodo & Areka & Total & Sodo & Areka & Total \\
\hline 1 & Small Construction & 160 & 146 & 306 & 22 & 24 & 46 \\
\hline 2 & Small Manufacturing & 68 & 80 & 148 & 10 & 12 & 22 \\
\hline 3 & Petty trade & 230 & 160 & 390 & 35 & 14 & 49 \\
\hline 4 & Beauty salons (men and Women) & 122 & 142 & 264 & 18 & 30 & 48 \\
\hline 5 & Small shopping & 220 & 218 & 438 & 24 & 33 & 57 \\
\hline 6 & Small transportation business & 126 & 88 & 214 & 19 & 13 & 32 \\
\hline 7 & Mini Market & 12 & 8 & 20 & 7 & 10 & 17 \\
\hline 8 & Shoe repair/Shoe shining & 40 & 60 & 100 & 6 & 8 & 14 \\
\hline 9 & Local coffee houses & 100 & 56 & 156 & 12 & 6 & 18 \\
\hline \multirow[t]{2}{*}{10} & Carpentry & 12 & 8 & 20 & 2 & 1 & 3 \\
\hline & Total & 1118 & 968 & 2036 & 155 & 151 & 306 \\
\hline
\end{tabular}

Table 1. Indicates the Population and Sample Distribution of IGAs in Sodo and Areka, wolaita zone, Ethiopia.

NB: By using stratified proportionate random sampling

\subsection{Data Sources}

\subsubsection{Primary Data Sources}

In order to realize the target, the study used well-designed questionnaire as best instrument. This was completed by the representatives of the group.

\subsubsection{Secondary Data Sources}

Secondary data from office manuals, circulars and policy documents used to provide additional information where appropriate. Besides, variety of books, published government documents, and reports reviewed to make the study fruitful.

\subsection{Data Collection Instruments}

\section{Questionnaires}

Questionnaires were prepared to collect the required data from youth groups in the study area. The layout of the questionnaire was kept very simple to encourage meaningful participation by the respondents. Five point Likert scale questionnaires were designed and used to examine how youths strongly agree or disagree with the statements on a five point scale. The type of scales used to measure the items on the instrument is continuous scales (strongly agree to strongly disagree).

\subsection{Data Processing and Analysis}

\subsubsection{Data Processing}

In the data processing procedures like editing, coding, classification and tabulation of the collected data was used.
Data processing has two phases namely: data clean-up and data reduction. During data clean-up the collected raw data could be edited to detect anomalies, errors and omissions in responses and checking that the questions are answered accurately and uniformly.

\subsubsection{Data Analysis}

This will be the further transformation of the processed data to look for patterns and relationship between and/or among data groups by using descriptive and inferential statistical analysis. To evaluate the effects of various internal and external factors on the growth and sustainability of micro and small enterprises, simple descriptive statistics and advanced statistical models (Pearson linear correlations and multiple regressions) was used with the help of statistical package for social sciences (SPSS) version 16 software. To know the impact and relationship of independent variables on the dependent variable (engagement), the regression function can be:

$$
\begin{aligned}
\mathrm{Y}= & \mathrm{a}+\beta_{1} \mathrm{X}_{1}+\beta_{2} \mathrm{X}_{2}+\beta_{3} \mathrm{X}_{3}+\beta_{4} \mathrm{X}_{4}+\beta_{5} \mathrm{X}_{5}+\beta_{6} \mathrm{X}_{6}+\beta_{7} \mathrm{X}_{7}+\beta_{8} \\
& \mathrm{X}_{8}+\varepsilon
\end{aligned}
$$

Where:

i. $Y=$ the engagement of youths in off-farm IGAs or dependent variable

ii. $\mathrm{X}_{1}=$ Entrepreneurial Factors, $\mathrm{X}_{2}=$ Technological factors, $\mathrm{X}_{3}=$ Institutional factors $\mathrm{X}_{4}=$ Cultural factors of youth, $\mathrm{X}_{5}=$ financial factors, $\mathrm{X}_{6}=$ Socio-Economic factors, $\mathrm{X}_{7}=$ Psychological Factors and $\mathrm{X}_{8}=$ Infrastructural factors are the explanatory variables. 
iii. $\varepsilon-$ Stochastic error.

iv. $a$ - is the intercept term- constant which would be equal to the mean if all slope coefficients are 0 .

v. $\beta 1-\beta 8$ are the coefficients associated with each independent variables which measure the change in the mean value of engagement of youth in off-farm IGAs, per unit change in their respective independent variables.

\subsection{Pilot Testing (Validity and Reliability)}

Pilot study was conducted to refine the methodology and test instrument such as a questionnaire before administering the final phase. A questionnaire was tested on potential respondents to make the data collecting instruments objective, relevant, suitable to the problem and reliable. Whenever a test or other measuring device is used as part of the data collection process, the validity and reliability of that test is important. Validity is the extent to which a test measures what it is supposed to measure. Reliability is the degree to which a test consistently measures whatever it measures.

Reliability of the Instruments

The researcher were selected a pilot group of 40 individuals from the target population to test the reliability of the research instrument. The aim is to correct inconsistencies arising from the instruments, which ensure that they measure what is intended. After piloting the researchers had made some amendments' on questionnaires. In this study each statement rated on a five point Likert response scale which includes strongly agree, agree, undecided, disagree and strongly disagree. Based on this an internal consistency reliability test was conducted in Sodo and Areka towns of Wolaita Zone with a sample of 40 youth groups and the Cronbach's alpha coefficient for the instrument was found as 0.722 which is reliable. Typically an alpha value of 0.70 or higher is taken as a good indication of reliability.

\section{Results}

\subsection{General Backgrounds of the Respondents}

This implies that the general background information of the study respondents.

Table 2. Age, Sex, and Educational status of the youths.

\begin{tabular}{llll}
\hline & Category & Frequency & Percent \\
\hline \multirow{3}{*}{ Age } & $18-22$ & 124 & 40.52 \\
& $23-29$ & 182 & 59.48 \\
\multirow{3}{*}{ Sex of the respondents } & Male & 192 & 62.74 \\
& Female & 114 & 37.26 \\
& Total & 306 & 100 \\
Education & Secondary education & 32 & 10.45 \\
& College diploma & 135 & 44.13 \\
& Degree & 139 & 45.43 \\
Marital Status & Total & 100 & 100 \\
& Married & 28 & 9.16 \\
& Unmarried & 278 & 90.84 \\
\hline
\end{tabular}

Source: field survey: 2019

The above table 2 gives the clue about the age of respondents from the 306 respondents, $40.52 \%$ were under age group of 18-22 years, and 59.48\% were under age group of 2329 years. From the table information, the researchers concluded that the respondents were fully youth's age groups.

The above table 2 also showed that the $62.74 \%$ of respondents were male and $37.26 \%$ were female and this shows that women youth were also participated in Income generating activities.

Among 306 sample respondents, (32) 10.45\% were completed secondary school, (135) $44.13 \%$ were College Diploma holders, and (139) 45.43\% were first degree graduates. The percentage of graduates from higher institutions was high and the researchers concluded that however they attended the but there is still big gap on identification of income generating activities that are important to change their life.

The above table 2 also showed the marital status of the respondents. From the 306 sample respondents, (28) $9.16 \%$ were married and (278) 90.84\% were unmarried. The researcher realized that most the respondents were youths and unmarried.

\subsection{Correlation Analysis}

In this section, the results of inferential statistics are presented. For the purpose of assessing the objectives of the study, Pearson's Product Moment Correlation Coefficient and regression analysis were performed. With the aid of these statistical techniques, conclusions are drawn with regard to the sample and decisions are made with respect to the research hypothesis. 


\subsubsection{Pearson's Product Moment Correlation Coefficient}

Table 3. The relationship between engagement of youths in off-farm IGAs and affecting factors.

\begin{tabular}{|c|c|c|}
\hline Affecting Factors & $\begin{array}{l}\text { Correlations, probability values and } \\
\text { sample size }\end{array}$ & $\begin{array}{l}\text { Engagement of Rural youths in Off-farm IGAs (value of } \\
\text { Correlations, probabilities and sample size) }\end{array}$ \\
\hline \multirow{3}{*}{$\begin{array}{l}\text { Engagement of Rural youths } \\
\text { in Off-farm IGAs (Y) }\end{array}$} & Pearson Correlation & 1 \\
\hline & Sig. (2-tailed) & \\
\hline & $\mathrm{N}$ & 306 \\
\hline \multirow{3}{*}{ Entrepreneurial Factors (X1) } & Pearson Correlation & $.484^{* *}$ \\
\hline & Sig. (2-tailed) & .000 \\
\hline & $\mathrm{N}$ & 306 \\
\hline \multirow[t]{2}{*}{ (Technological Factors) X2 } & Sig. (2-tailed) & .000 \\
\hline & $\mathrm{N}$ & 306 \\
\hline \multirow{3}{*}{ (Institutional Factors) X3 } & Pearson Correlation & $.585^{* *}$ \\
\hline & Sig. (2-tailed) & .000 \\
\hline & $\mathrm{N}$ & 306 \\
\hline \multirow[b]{2}{*}{ (Cultural Factors) X4 } & Pearson Correlation & .025 \\
\hline & Sig. (2-tailed) & 669 \\
\hline \multirow[t]{2}{*}{ (Financial Factors) X5 } & Sig. (2-tailed) & .000 \\
\hline & $\mathrm{N}$ & 306 \\
\hline \multirow{3}{*}{ (Socio-economical factors) X6 } & Pearson Correlation & $.657^{* *}$ \\
\hline & Sig. (2-tailed) & .000 \\
\hline & $\mathrm{N}$ & 306 \\
\hline \multirow{3}{*}{ (Psychological Factors) X7 } & Pearson Correlation & $.667^{* *}$ \\
\hline & Sig. (2-tailed) & .000 \\
\hline & $\mathrm{N}$ & 306 \\
\hline \multirow{3}{*}{ (Infrastructural Factors) X8 } & Pearson Correlation & .073 \\
\hline & Sig. (2-tailed) & .206 \\
\hline & $\mathrm{N}$ & 306 \\
\hline
\end{tabular}

**. Correlation is significant at the 0.01 level (2-tailed).

*. Correlation is significant at the 0.05 level (2-tailed).

The above table 3 provides a matrix of the correlation coefficients for the dependent variable engagement of rural youth on off-farm in IGAs and eight independent variables (correlation direction, strength and significance). Each variable is perfectly correlated with itself and so correlation $=1$ along the diagonal of the table.

There is a positive relationship was found between entrepreneurial factors and engagement youths on rural off-farm IGAs $(\mathrm{r}=0.484, \mathrm{P}<0.05)$, which is moderate and it implies that an increase in entrepreneurial knowledge constraints results in a decrease in engagement on rural off-farm IGAs. Also there is also moderate, however statistically significant relationship between technological factors and engagement on Rural offfarm IGAs $(\mathrm{r}=0.533, \mathrm{P}<0.05)$. This would imply that, the technological factors are play crucial role in the engagement of rural youths in off-farm Income generating activities.

The result on table above further indicates that, there is a substantial positive correlation between institutional factors and engagement of rural youths in off-farm IGAs $\left(\mathrm{r}=.585^{* *}\right.$, $\mathrm{p}<0.05$ ), which is statistically significant at $99 \%$ confidence level. This implies that institutional factors are the major factors which affecting the engagement of rural youths in offfarm IGAs. As it is indicated in the table there is in significant correlation between cultural factors and engagement of rural youths in off-farm IGAs which has very weak relationship $(\mathrm{r}=.026 \mathrm{p}<0.05)$. This shows that cultural influences the engagement of youths at very weak level.

There exists a strong positive relationship between financial factors and engagement of rural youths in off-farm IGAs ( $\mathrm{r}$ $=.634, \mathrm{p}<0.05)$, which indicates that an increase in financial support or startup capital issues has positive impact on the rural youths IGAs selection and the reverse is true for decrease in financial factor and vice versa. Association of socio-economic factors with engagement of youths in rural off-farm IGAs is ( $\mathrm{r}$ $=.657, \mathrm{P}<0.05$ ) which means there is strong correlation and it implies that there is high socio economic factors such as unemployment, inflation etc that are influencing the youths not to engage in non agricultural activities.

Findings also indicated that the association between psychological factors and engagement youths in rural off-farm IGAs is strong, $(\mathrm{r}=.667, \mathrm{P}<0.05)$ which implies that an increase in psychological factors has more impacts on youths not to engage in non-farm income generating activities. Association of infrastructural factors with engagement youths in rural off-farm IGAs is $(\mathrm{r}=.073, \mathrm{P}<0.05)$ which is very weak and it implies that an increase in infrastructural constraint results in a decrease in engagement youths in rural off-farm IGAs.

\subsubsection{Correlation Coefficient Squared (R2)}

The correlation coefficient squared (known as the coefficient of determination, $R^{2}$ ) is a measure of the amount of variability in one variable that is shared by the other. 
Table 4. Correlation coefficient squared of dependent and independent variables.

\begin{tabular}{lllll}
\hline No & Affecting Factors & Correlation & $\begin{array}{l}\text { correlation coefficient } \\
\text { squared }\left(\mathbf{R}^{2}\right)\end{array}$ & $\begin{array}{l}\text { Extent of Engagement of Youths in Off-Farm IGAs } \\
\text { affecting variance shared by each factor }\end{array}$ \\
\hline 1 & Entrepreneurial Factors & 0.484 & 0.2342 & 23.42 \\
2 & Technological Factors & 0.533 & 0.2840 & 28.4 \\
3 & Institutional Factors & 0.585 & 0.3422 & 34.22 \\
4 & Cultural Factors & 0.025 & 0.0625 & 0.06 \\
5 & Financial Factors & 0.634 & 0.4019 & 40.19 \\
6 & Socio - -conomical factors & 0.657 & 0.4316 & 43.16 \\
7 & Psychological Factors & 0.667 & 0.4448 & 44.48 \\
8 & Infrastructural Factors & 0.073 & 0.0053 & 0.53 \\
\hline
\end{tabular}

Source: Field study (2019)

The engagement of rural youths in off-farm IGAs really varies from one youth groups to another youth groups because of any number of factors (different ability, different levels of working and so on). $R^{2}$ is to show that how much of this variability is shared by each factor. Other factors remains constant psychological factors show the variance of $44.48 \%$ shares and socio economic factors shared $43.16 \%$ influence on the engagement of youths in off-farm activities variances. Financial factors shares $40.19 \%$, institutional factor shares $34.22 \%$ and technological factor also shares $28.4 \%$ variance. Entrepreneurial factors shared $23.42 \%$ of the engagement of youths in off-farm activities constraints variances. Cultural and infrastructural constrain shares $0.06 \%, 0.53 \%$ respectively on youth engagement in off-farm IGAs. The researcher concluded that the from the given constraints psychological and socio-economical factors scored to the highest extent affecting factors where as cultural and infrastructural factors affecting variables with variance to the low level.

\subsection{Multiple Regression Analysis}

Multiple regressions is a logical extension of these principles to situations in which there are predictors and each predictor variable has its own coefficient, and the outcome variable is predicted

Table 5. The model summary of regression Analysis.

\begin{tabular}{|c|c|c|c|c|c|c|c|c|c|c|}
\hline \multicolumn{11}{|c|}{ Model Summary } \\
\hline \multirow{2}{*}{ Model } & \multirow{2}{*}{$\mathbf{R}$} & \multirow{2}{*}{ R Square } & \multirow{2}{*}{$\begin{array}{l}\text { Adjusted } \\
\text { R Square }\end{array}$} & \multirow{2}{*}{$\begin{array}{l}\text { Std. Error of } \\
\text { the Estimate }\end{array}$} & \multicolumn{5}{|l|}{ Change Statistics } & \multirow{2}{*}{$\begin{array}{l}\text { Durbin- } \\
\text { Watson }\end{array}$} \\
\hline & & & & & R Square Change & F Change & df1 & df2 & Sig. F Change & \\
\hline 1 & $.859^{\mathrm{a}}$ & 0.737 & 0.73 & 0.492 & 0.737 & 104.103 & 8 & 297 & 0 & 1.852 \\
\hline
\end{tabular}

a. Predictors: (Constant), X1, X2, X3, X4, X5, X6, X7 and X8

b. Dependent Variable: Engagement of Rural youths in Off-farm IGAs (Y)

The regression summary model indicated that the coefficient (R) with a value of 0.859 and co-efficient of determination $\left(\mathrm{R}^{2}\right)$ with the value of 0.737 or $73.7 \%$ confirms that the identified Rural youth Income generating activities factors attributes $73.7 \%$ while the remaining 26.3 percent could be explained by other Rural youth Income generating activities factors which did not included in this study. To conclude that, among eight identified study variables, six variables (Entrepreneurial, technological, institutional, financial, socio -economic and psychological) are statistically significant $(\mathrm{p}<0.05)$ while the remaining three variables (cultural and infrastructural) factors were not statistically significant because of their $p$-value is greater than predetermined level $(\mathrm{p}>0.05)$.

\subsubsection{One Way ANOVA (Analysis of Variance)}

The study further used one way Analysis of Variance (ANOVA) in order to test the significance of the overall regression model.

Table 6. One way ANOVA (analysis of variance).

ANOVA $^{\mathrm{b}}$

\begin{tabular}{llllll}
\hline Model & & Sum of Squares & Df & Mean Square & F \\
\hline \multirow{2}{*}{1} & Regression & 201.214 & 8 & 25.152 & 104.103 \\
& Residual & 71.757 & 297 & 0.242 & $.000^{\mathrm{a}}$ \\
& Total & 272.971 & 305 & & \\
\hline
\end{tabular}

a. Predictors: (Constant), infrastructural, Technological, Cultural, Socio economical, Entrepreneurial, Financial, Institutional, Psychological

b. Dependent Variable: Engagement of Rural youths in Off-farm IGAs (Y)

Table 6, hence shows the regression and residual (or error) 
the value of the mean square which is 25.152 . The predictors $\mathrm{X}_{1}$ up to $\mathrm{X}_{8}$ (Entrepreneurial, technology, institutional cultural, financial, socio-economic and psychological, and infrastructural) represent the independent variables as the major factors determining the engagement of youths in rural off farm IGAs in the area.

The results of ANOVA test which reveal that the eight independent variables notably; have a significance influence on engagement of rural youths in Off-farm IGAs. Since the $\mathrm{P}$ value is actual 0.00 which is less than $5 \%$ level of significance is large enough to conclude that the entrepreneurial and infrastructural, financial, technological and political-legal significantly determine engagement of rural youths in Off-farm IGAs in the Sodo and Areka towns.

\subsubsection{Coefficients of Multiple Regressions}

Table 7. Prediction of the engagement of rural youths in off-farm IGAs by using Coefficients of regression.

\begin{tabular}{|c|c|c|c|c|c|c|c|c|}
\hline \multirow{2}{*}{\multicolumn{2}{|c|}{ Model }} & \multicolumn{2}{|c|}{$\begin{array}{l}\text { Unstandardized } \\
\text { Coefficients }\end{array}$} & \multirow{2}{*}{$\begin{array}{l}\text { Standardized } \\
\text { Coefficients } \\
\text { Beta } \\
\end{array}$} & \multirow[t]{2}{*}{$\mathbf{T}$} & \multirow[t]{2}{*}{ Sig. } & \multicolumn{2}{|c|}{ Collinearity Statistics } \\
\hline & & B & Std. Error & & & & Tolerance & VIF \\
\hline \multirow{8}{*}{1} & (Constant) & -0.641 & 0.132 & & -4.863 & 0 & & \\
\hline & Entrepreneurial factors (X1) & 0.106 & 0.036 & 0.101 & 2.94 & $.004 * *$ & 0.743 & 1.345 \\
\hline & (Technological Factors) X2 & 0.13 & 0.035 & 0.131 & 3.712 & $.000 * *$ & 0.713 & 1.403 \\
\hline & (Institutional Factors) X3 & 0.216 & 0.035 & 0.227 & 6.255 & $.000 * *$ & 0.674 & 1.483 \\
\hline & (Cultural Factors) X4 & 0.03 & 0.025 & 0.037 & 1.187 & 0.236 & 0.924 & 1.082 \\
\hline & (Socio-economical factors) X6 & 0.284 & 0.038 & 0.275 & 7.478 & $.000 * *$ & 0.653 & 1.53 \\
\hline & (Psychological Factors) X7 & 0.259 & 0.039 & 0.253 & 6.625 & $.000 * *$ & 0.606 & 1.651 \\
\hline & (Physical Factors) X8 & 0.073 & 0.027 & 0.083 & 2.66 & $.008 *$ & 0.899 & 1.112 \\
\hline
\end{tabular}

a. Dependent Variable: Engagement of Rural youths in Off-farm IGAs (Y)

As indicated in the above table 7, the Sig -value proves or disproves the significance of the impact. A Sig- value is said to be significant if it is less than the level of significance, (1\%) except cultural factors. If the Sig-value is considered significant (is less than the specified level of significance), and the null hypothesis is false, otherwise it become true. To make the discussion on the previously formulated hypothesis, the above table is used to decide on it.

In table the regression model above has established that taking eight independent variables into account notably; X1$\mathrm{X} 8$ constant at Zero influences, rural youth engagement in Off-farm IGAs will be (- 0641). The results presented also shows that taking all other independent variables at zero, an engagement of rural youths income generation activities/IGAs/ are negatively affected by X1-X8 independent variables. Therefore, the inferences can be made that $\mathrm{X} 1-\mathrm{X} 8$ determines the engagement of youth in rural generating activities. From the regression findings, the substitution of the equation (2) becomes:

$$
\begin{aligned}
\mathrm{Y}= & -0.641+.0 .106 \mathrm{X} 1+0.130 \mathrm{X} 2+0.216 \times 3+0.030 \mathrm{X} 4+ \\
& 0.206 \times 5+0.284 \times 6+0.259 \times 7+0.073 \times 8
\end{aligned}
$$

Where $\mathrm{Y}$ is the dependent variable (engagement of youth in rural generating activities) $\mathrm{X}_{1}-\mathrm{X}_{8}$ are predictors. According to the equation, taking all factors constant at zero, the engagement of youth in rural generating activities will be 0.641. From the results, X6 (Socio-economic).

constraint) as a component of engagement of youth in offfarm IGAs contributes most to the engagement of youths offfarm in IGAs, which has the greatest t- value of 7.478, while Cultural factor (X4) contributes the least, which has the smallest t- value of 1.187 .

\subsection{Hypothesis Testing}

Table 8. Hypothesis Testing.

\begin{tabular}{lll}
\hline Factors affecting the engagement of youths in rural off-farm IGAs & sig & P- Values \\
\hline Entrepreneurial knowledge $(\mathrm{X} 1)$ & $0.004^{* *}$ & $\mathrm{P}=0.004, \mathrm{p}<.05$ \\
(Technological Factors) X2 & $0.000^{* *}$ & $\mathrm{P}=0.000, \mathrm{p}<.05$ \\
(Institutional Factors) X3 & $0.000^{* *}$ & $\mathrm{P}=0.000, \mathrm{p}<.05$ \\
(Cultural Factors) X4 & 0.236 & $\mathrm{P}=0.236, \mathrm{p}>.05$ \\
(Financial Factors) X5 & $0.000^{* *}$ Accepted & $\mathrm{H}_{0}$ Accepted \\
(Socio-economical factors) X6 & $0.000^{* *}$ & $\mathrm{P}=0.000, \mathrm{p}<.05$ \\
(Psychological Factors) X7 & $\mathrm{P}=0.000, \mathrm{p}<.05$ \\
(Infrastructural factors (X8) & $0.000^{* *}$ & $\mathrm{P}=0.000, \mathrm{p}>.05$ \\
\hline
\end{tabular}

** Significance $(\mathrm{p}<5 \%$ or 0.05$)$

Explanation Hypothesis testing

Hypothesis - 1 Entrepreneurial factors $\left(\mathrm{X}_{1}\right)$ has a significant influence on the engagement of rural youths in off-farm IGAs $(\mathrm{P}=0.004, \mathrm{P}>0.05)$. Hence the hypothesis 
which stated as entrepreneurial factors $\left(\mathrm{X}_{1}\right)$ has a significant influence on the engagement of rural youths in off-farm IGAs in Sodo and Areka Towns was accepted.

Hypothesis - 2 Findings also indicated that the technological factors $\left(\mathrm{X}_{2}\right)$ has a significant influence on the on the engagement of rural youths in off-farm IGAs $(\mathrm{P}=$ $0.000, \mathrm{P}<0.05)$. Thus the hypothesis that technological factors have a significant impact entrepreneurial growth and sustainability of Sodo and Areka towns was accepted.

Hypothesis - 3 In addition, findings revealed that institutional factors $\left(\mathrm{X}_{3}\right)$ has a significant influence on the engagement of rural youths in off-farm IGAs $(\mathrm{P}=0.000, \mathrm{P}<$ $0.05)$. Hence the hypothesis which stated as a institutional factor has a significant impact on engagement of rural youths in off-farm IGAs of Soddo and Areka towns' zones was accepted.

Hypothesis - 4 Findings indicated that cultural factors $\left(\mathrm{X}_{4}\right)$ has insignificant influence on the engagement of rural youths in off-farm IGAs $(\mathrm{P}=0.236, \mathrm{P}>0.05)$. Thus the hypothesis that stated cultural factor has a significant influence on the engagement of rural youths in off-farm IGAs of Sodo and Areka zones was rejected.

Hypothesis - 5 Findings indicated that Financial factors $\left(\mathrm{X}_{4}\right)$ has a significant influence on the engagement of rural youths in off-farm IGAs $(\mathrm{P}=0.000, \mathrm{P}<0.05)$. Thus the hypothesis that financial factors has a significant influence on the engagement of rural youths in off-farm IGAs of Sodo and Areka zones was accepted.

Hypothesis - 6 Findings indicated that socio-economic factors $\left(\mathrm{X}_{6}\right)$ has a significant impact on the engagement of rural youths in off-farm IGAs $(\mathrm{P}=0.000, \mathrm{P}<0.05)$. Thus the hypothesis stated that a socio-economic factor has a significant influence on the engagement of rural youths in off-farm IGAs in Sodo and Areka town was accepted.

Hypothesis - 7 Findings revealed that psychological factors $\left(\mathrm{X}_{7}\right)$ has significant influence on the engagement of rural youths in off-farm IGAs $(\mathrm{P}=0.000, \mathrm{P}<0.05)$. Hence the hypothesis which stated as Psychological factors has a significant influence on engagement of rural youths in off-farm IGAs in Areka and Sodo Towns was accepted.

Hypothesis - 8 Findings indicated that an infrastructural factor $\left(\mathrm{X}_{8}\right)$ has a significant influence on the engagement of rural youths in off-farm IGAs in Areka and Sodo Towns. Thus the hypothesis which stated as an infrastructural factors has a significant influence on engagement of rural youths in off-farm IGAs in Areka and Sodo Towns was accepted because of $(\mathrm{P}=.008, \mathrm{p}<.05)$.

To summarize the hypothesis testing, among eight determinant variables that affect engagement of rural youths in off-farm IGAs in Areka and Sodo Towns. Seven factors were statistically significant and only one of them were statistically not significant at given level but this doesn't mean they have no influence on the engagement of rural youths in off-farm IGAs in Areka and Sodo Towns.

\section{Conclusion and Recommendations}

\subsection{Conclusion}

The study was carried out in Sodo and Areka Town in wolaita zone, Ethiopia, titled the factors influencing the engagement of rural youths in off-farm income generating activities in developing countries, Ethiopia. The youths in the area were involved in a number of (off-farm) non-agricultural income generating activities. The study established the factors that affect the engagement of rural youths in off-farm income generating activities. Factors such as entrepreneurial skills, technological, institutional, cultural, financial, socioeconomical, psychological and infrastructural factors influenced engagement of rural youth in non-agricultural income generating activities. Based on the objectives and findings of the study, the researchers tried to conclude the study as follows:-

As indicated above discussion parts, 306 youth groups participated in this study. As shown in back ground information of sample respondents, the age of respondents was fully youth groups. The sex of respondents $62.74 \%$ of respondents was male and $37.26 \%$ were female and this shows that youth women were also participated in income generating activities. As indicated in the output of the research the percentage of graduates from higher institutions was high $44.13 \%$ (College Diploma holders) and $45.43 \%$ (first degree graduates) and the researchers concluded that however they attended the higher institutions but there is still big gap on identification of income generating activities that help the youths to participate in their local areas in long run the IGAs will change their life.

The researcher used factor analysis to reduce invalid variables from further analysis and unloaded variables ignored from further analysis. Internal and external constraints that are currently affecting the engagement of youths in rural off-farm activities in Sodo and Areka towns include entrepreneurial, technological, institutional, cultural financial, socio-economic, psychological and infrastructural factors. The institutional and entrepreneurial factors are internal factor from eight study variables and their strength of association with the engagement of the youths in off-farm IGAs was significant. External factors which are affecting the engagement of the youths in off-farm activities in two towns in wolaita zone were cultural, financial, technological, socioeconomical, and infrastructural constraints. The multiple regression model analysis result revealed that among eight study variables, 7 (seven) variables were statistically significant because their p-value is less than predetermined level and from previously formulated hypothesis testing 7 were accepted and one of the hypotheses rejected because of their p-value more than significant level. Finally the research output conclude that the variables identified under this study predicted variance of $73.7 \%$ influences the youth's engagement in off-farm income generating activities /IGAs/ in Sodo and Areka Towns. Whereas 26.3\% of the engagement of youths in off-farm income generating activities affecting factors cannot be explained by other 
factors which are not the part of this study variables.

\subsection{Recommendations}

Based on the finding results and conclusions of the study, the researcher forwarded the following recommendations:-

To curtail the factors that influence the engagement among rural youths in off-farm IGAs, the wolaita zone Rural Job Opportunity Creation Department (RJOCD) should create a good environment by encouraging a good trainer and trainee relationship and other capacity building methods to support so that they will feel engrossed and psychologically present at the activity which will foster their engagement on off-farm IGAs. Technological awareness creation program should be arranged in the towns on IGAs regular basis, more focus should be given to enhance youth entrepreneurial skill and empower on their psychological advice, encourage the youths on financial and economic support should be accelerated to youth through MFI.

Determinants such as entrepreneurial, and infrastructural factors are internal to the engagement of rural youth in offfarm IGAs, they should increase their internal capability through continuous and periodic evaluation and mange this factors themselves.

The study recommends that youths should be sensitized on the importance of involving in income generating activities as this will help them to be self-reliant. It also recommended that youths should be encouraged to attend the entrepreneurial skills, they have to use different types of technological instruments to get important information and new inventions and have to take trainings regarding to off-farm income generating activities. In order to improve on their performance in the engagement of IGAs, the local government should assist youths by linking them with financial institutions so as to acquire loan and youths should be encouraged to form cooperative groups for easier access to loans.

Finally, the internal and external constraints identified in this study were explained the variance of $73.7 \%$ of youth engagement of youths in off-farm activities affecting factors whereas the $26.3 \%$ variance of youth engagement of youths in off-farm activities affecting factors cannot be explained by this study, So it is advisable to the other potential researchers to conduct the research on the area of youths in income generating Activities in the area.

\section{Acknowledgements}

The authors thank Sodo and Areka towns, wolaita zone Rural Job Opportunity Creation Department officials for providing all necessary data.

\section{References}

[1] Barrett, C. B., et al. (2001). "Nonfarm income diversification and household livelihood strategies in rural Africa: concepts, dynamics, and policy implications." Food policy 26 (4): 315331 .
[2] Bereket, 2010. The Role of Micro and Small Enterprises in Employment Creation and Income Generation A Survey Study of Mekelle City, Tigray Region, Ethiopia, 14-15.

[3] Bezabih, M., Gebreegziabher, Z., Gebremedhin, L., \& Köhlin, G. (2010). Participation in off-farm employment, rainfall patterns, and rate of time preferences: The case of Ethiopia (No. dp-10-21-efd). Retrieved from https://www. rff.org/RFF/documents/EfD-DP-10-21.pdf

[4] Carletto G., Covarrubias K., Davis B., Krausova M., Stamoulis K., Winters P. and Zezza A. (2007). Rural Income Generating Activities in Developing Countries. Journal of Agricultural and Development Economics, 4 (1): 146-193.

[5] Central statistics Agency (CSA), Ethiopia, reports on youth and unemployment, 2011

[6] Charity, N. (2011). Empowerment and women's participation in development processes: A study of Nsukka community (Unpublished master's thesis). University of Nsukka, Enugu state, Nigeria.

[7] De Janvry A., Sadoulet E. and Zhu N. (2005). The role of nonfarm Incomes in Reducing Poverty and Inequality in China, CUDARE Working papers 1001. Berkely, University of California.

[8] Food and Agricultural Organisation (FAO). Women in infrastructure works: Boosting gender equality and rural development. Gender and Rural Employment Policy Brief; 2010.

[9] Fletschner, D., \& Kenney, L. (2014, March). Rural women's access to financial services: credit, savings, and insurance. Gender in agriculture 11 (7), 187-208.

[10] Helena, M. C. C. (2000). The impact of culture on perceptions of organizational justice. Unpublished master's thesis, Institute of Psychology, Universidade Gama Filho, Rio de Janeiro, RJ.

[11] Lanjouw, J. O. and Lanjouw P. (2001). The Rural Non-Farm Sector: Issues and Evidence from Developing Countries. Agricultural Economics, 26 (1): 1-23.

[12] Ovwigho B. O. (2014). Factors Influencing Involvement in Nonfarm Income Generating Activities among Local Farmers: The Case of Ughelli South Local Government Area of Delta State, Nigeria, Sustainable agriculture Research, 3 (1): 76-84.

[13] Reardon T. (1997). Using Evidence of Household Income Diversification to Inform Study of the Rural Nonfarm Labor Market in Africa. World Development, 25 (5): 735-748.

[14] Shivalingaiah Y. N. (1995). Participation of Rural Youth in Farm Activities, Ph.D thesis, University of Agirc. Science Banglore.

[15] Shortall, S. (2008). Are rural development programmes socially inclusive? Social inclusion, civic engagement, participation, and social capital: Exploring the differences. Journal of Rural Studies, 24 (4), 450-457.

[16] Umoru, D. (2013). Employment and Economic Growth in Nigeria: A Bounds Specification. Journal of Economics and Sustainable Development, 4 (5), 49-62.

[17] UNCTAD, W. (2011). Price Volatility in Food and Agricultural Markets: Joint Policy Responses. Reports contributions by FAO, IMF, UN HLTF, WFP, World Bank, the WTO and IFPRI. 
[18] United Nations (2007). World Youth Report. 2007. New York: United Nations ILO (2004), Global employment trends for youth, Geneva.

[19] World Bank. (2003). Reaching the Rural Poor: A Renewed Strategy for Rural Development. Washington, DC: The World Bank.
[20] Yamane, Taro. (1967). Statistics: An Introductory Analysis, 2nd Edition, New York: Harper and Row. 